\title{
Partisipasi Politik dalam Pemerintahan Non Muslim Perspektif Yusuf Qardawi
}

\author{
Sugianto *) \\ Institut Agama Islam An-Nur \\ Lampung Selatan, Lampung \\ sugiantoalfaruqi3@gmail.com
}

\section{Rahmat Hidayat}

Universitas Islam Negeri Raden Intan Lampung

hidayatrahmat677@gmail.com

\section{Agus Sujarwo}

Institut Agama Islam An-Nur Lampung Selatan, Lampung gssujarwo07@gmail.com

*) Corresponding Author

\begin{abstract}
This study aims to reveal the thoughts of Yususf Qordawi about Muslim political participation in non-Muslim governments. Data obtained from the main source in the form of the book ghoiru Muslim fi al-mujtama 'al Islami (non-Muslim minority in the Islamic society). Then the data were analyzed using the content analysis method. The results showed that the existence of a Muslim must be carried out within the framework of the state and society life order as an implementation of obedience to the leader. This thought is based on the interpretation of fundamental Islamic values in the sentence rahmatan lil 'alamin, in every case it must be placed in a balanced place and in accordance with the rules or laws that apply in the region. So Muslim participation in non-Muslim governments is allowed.
\end{abstract}

Abstrak: Penelitian ini bertujuan untuk mengungkap pemikiran Yususf Qordawi tentang partisipasi politik Muslim dalam pemerintahan non Muslim. Data diperoleh dari sumber utama berupa buku ghoiru Muslim fi al-mujtama' al Islami (minoritas non Muslim di dalam masyarakat Islam). Kemudian data tersebut dianalsis dengan metode analisis isi. Hasil penelitian menunjukan bahwa eksistensi seorang Muslim harus dilaksanakan dalam bingkai tatanan kehidupan bernegara dan bermasyarakat sebagai pelaksanaan dari ketaatan kepada Pemimpin. Pemikiran tersebut didasari atas interpretasi akan nilai Islam yang fundamental pada kalimat rahmatan lil 'alamin, dalam setiap perkara mesti diletakan ditempatnya dengan seimbang dan sesuai dengan aturan ataupun Undang-Undang yang berlaku diwilayah tersebut. Jadi partisipasi politik Muslim dalam pemerintahan non Muslim diperbolehkan.

Kata Kunci: Politik, Relasi Agama, Negara

\section{PENDAHULUAN}

Pergulatan di dalam dunia Islam yang sangat menarik untuk dikaji dan dijadikan sebuah komunikasi dalam perbincangan ialah permasalahan antara agama dan negara atau sebaliknya. Dengan menempuh jarak dan kurun waktu yang sangat kompleks beserta dinamikanya, diskusi tersebut masih sangat relevan untuk dibincangkan dalam rangka menemukan titik ahir. Begitupun Islam menjelaskan sistem-sistem kerumitan tersebut sebagai bentuk dan buah fikir dari intelektual muslim yang kemudian hari dijadikan paradigma kepercayaan kaitannya dengan politik. Maka banyak tokoh intelektual yang mengidentikan antara agama dan negara ialah dua instrument yang saling membutuhkan dalam kehidupan masyarakat religius (agama) dan hukum (konstitusi).

Misalnya jargon rela berkorban jiwa dan raga demi negara, sama halnya mengorbankan jiwa dan raga demi agama. Maka tidak jarang pula individu rela mengorbankan segalanya dan tanpa berfikir panjang atas keyakinannya. Alur berfikir tersebut dalam islam dikenal dengan istilah syahid, sedangkan dalam bernegara dikenal dengan istilah pahlawan. 
Istilah syahid dan pahlawan merupakan cerminan bahwa agama dan Negara saling membutuhkan. (Ahmad A. Sofyan \& M. Raoychan Madjid, 2003, h. 12). Berkaitan dengan hal tersebut, term negara merupakan pengejawentahan dari bahasa Indonesia yang berarti. Satu, organisasi disuatu wilayah dengan kekuasaan sah terakui, ditaati sebagai kekuasan tertinggi oleh rakyat. Dua, wilayah kelompok sosial yang duduk dan terorganisir di dalam naungan lembagalembaga politik atau pemerintahan yang berdaulat dengan memiliki hak dalam melaksanakan cita-cita bersama secara nasional (Kamaruzzaman, n.d., h. 685).

Namun bukan hal tersebut yang hendak diteladani dalam membangun dan membentuk mentalitas hati Muslim. Ketika hidup berdampingan dengan menyamakan persepsi menjadi kepentingan bersama, bahwa Islam mengakomodir segala kemaslahatan bagi seluruh alam. Keinginan tersebut sudah mendeskripsikan bahwasanya Islam yang rahmatan lil a'lamin menjadi konsepsi dalam membangun segala fungsi dan sendi kehidupan syariat Islam secara menyeluruh. Prihal ini akan semakin dipertegas bahwa Islam menghendaki kedamaian dan menolak kekerasan agama. Bukan agama yang mengajarkan ekstrimisme, radikalisme dan terorisme dalam mengekspansi pemikiranpemikirannya (Sugianto \& Hidayat, 2021, h. 26).

Kemudian bila kita menyinggung sebuah gagasan siapa yang akan menjadi leader atau pemimpin, ialah dia individu yang mumpuni dan memiliki kemampuan dalam mempengaruhi, memutuskan, menggerakan dan mengkoordinasikan orang lain untuk turut bersamanya dalam mewujudkan cita-cita bersama (Sobry Sutikno, 2014, 9). Pemimpin harus mampu melihat dan memahami segala sub-sub bagian terkecil dalam kehidupan bermasyarakat, yang dalam hal ini merupakan buah kunci keberhasilan dari seorang pemimpin. Namun dalam konsep Islam, kaitanya dengan pemimpin ialah keimanan dan aqidah dalam menegakkan syariat Islam sebagai pondasi dasar di dalam menjalankan roda pemerintahan.

Sukses tidaknya sebuah kelompok masyarakat sangat tergantung pada kemampuan pemimpin (leader) di dalam menggerakkan seluruh anggota untuk mencapai tujuan. Pemimpin merupakan manusia pilihan yang jumlahnya sedikit, namun perannya dalam masyarakat merupakan penentu keberhasilan dan suksesnya tujuan yang hendak dicapai. Walaupun bukan satu-satunya ukuran keberhasilan, akan tetapi kenyataan membuktikan bahwa tanpa kehadiran pemimpin, suatu kelompok masyarakat akan statis dan cenderung berjalan tanpa arah. Keharusan untuk memilih pemimpin diatur dalam Undang-undang Dasar (UUD) tahun 1945 pada Pasal 6 ayat 1 dan Undang-undang Nomor 32 Tahun 2004 tentang Pemerintahan Daerah yang menyebutkan bahwa kepala daerah dipilih secara langsung oleh rakyat melalui Pemilihan Kepala Daerah dan Wakil Kepala Daerah atau disingkat Pilkada (Tim Sinar Grafika, 2005, h. 41).

Berdasarkan peraturan tersebut, sangat jelas bahwasanya setiap warga negara memiliki hak untuk dipilih ataupun memilih pemimpin. Baik hal tersebut dalam wilayah Republik Indonesia (Presiden/ Wakil Presiden) maupun suatu daerah baik Provinsi (Gubernur/ Wakil Gubernur), Kabupaten/ Kota (Bupati/ Walikota) tanpa membedakan agama atau keyakinan yang dianutnya. Asas inilah yang dijunjung dalam melakukan sebuah proses demokrasi sebagia alat penentu yang dianggap layak untuk menjadi seorang pemimpin dikalangannya. 
Yusuf Qordowi juga menyadari bahwasanya segala upaya yang dijalankan dalam menerapkan tatanan demokrasi haruslah ditunjang dengan kondisi dan stamina yang kuat dari seluruh kalangan masyarakat yang bernaung di bawah kepemimpinan negara. Dikarenakan dalam menjalankan roda pemerintahan tentunya akan banyak menuai berbagai rintangan bahkan tantangan berfariatif dan kompleks dengan kerumitannya. Ini disebabkan demokrasi bukanlah hanya semata masalah yang gampang dan bukan pula suatu perpindahan atau perubahan dari tahapan ketahapan lainnya, akan tetapi akan melahirkan hal-hal baru beserta kerumitan dan permasalahannya. (Muhammad Ābid al-Jābiri, 2003, h. 39-40). Artinya pergerakan sebuah negara yang dijalankan oleh segala unsur masyarakat dalam menjalankan sistematika bernegara, menjadi sebuah keharusan mutlak dalam bernegara.

Dengan uraian tersebut, maka menelusuri gagasan tentang konsep-konsep negara yang diungkapkan oleh Yususf Qordowi memiliki keunikan tersendiri dengan beberapa tokoh pada kalangan lainya yang membahas akan eksistensi sebuah pergerakan dan perjalanan sebuah negara. Oleh sebab itu, pembahasan yang sangat menarik apabila dapat mengeksplornya lebih jauh mengenai pemikiran yususf Qardawi mengenai konsep bernegara khususnyya partisipasi muslim dalam pemerintahan yang dipimpin non muslim.

Meskipun pemikiran tersebut dari masa yang berbeda. Penulis mencoba untuk menarasikan dan mengungkap pemikiran seorang tokoh Yusuf Qardhawi yang banyak menyatakan sebuah eksistensi Tuhan atas sebuah pemikiran atau membangun landasan dan pondasi bernegara yang beliau ungkapkan. serta partisipasinya masyarakat Muslim dalam urusan di dalam negara dengan mayoritas penduduk non-muslim.

Sebagaimana penelitiannya Zuhraini tentang Islam, Negara, demokrasi, hukum dan politik. Zuhraini mengungkap pemikiran Qordawi bahwa Islam memberikan kepada umat Islam untuk berkontribusi dalam kenegaraan, khususnya politik (Zuhraini, 2014, h. 29).

Berbeda dengan penelitiannya Rashda Diana, penelitiannya mengungkap bahwa pemikiran Qardawi tentang politik islam mencoba memadukan antara corak tradisionalisme dan Neo-tradisionalisme dalam memecahkan masalah perdebatan partisipasi politik muslim (Diana, 2009, h. 14).

Sedangakan Suhartono mengungkap pemikiran Qardhawi dari segi metodologi, menghasilkan sebuah kesimpulan bahwa dalam sudut siyasah hukum islam lebih fleksibel dibandingkan dari sudut ibadah. Oleh karena itu partisipasi politik muslim dalam pemerintahan non Muslim sangat diperbolehkan.

Berdasarkan paparan di atas, masih terdapat cela untuk dikaji lebih jauh mengenai pemikiran yusuf qardawi tentang partisipasi politik muslim dalam pemerintahan non muslim dan relevansinya dalam pemerintahan di Indonesia. Penelitian ini merupakan sebuah penelitian kepustakaan atau Library Research, yang sumber utamanya berupa buku. (Kartini Kartono, 1980, h. 28). Dengan mencantumkan sumber data primer dan merupakan kaidah yang dikarang ole Yusuf Qardhawi dalam Ghairul Muslimin fil Mujtama" Al Islami, yang merupakan terjemah Muhammad Baqir, Minoritas Non-Muslim di dalam Masyarakat Islam. Selanjutnya data tersebut dianalisa dengan menggunakan metode analisis isi (Noeng Muhajir, 1996, h. 49) dengan menggunakan analisis diskursus kritis. Hal ini sebagaimana pendapat Marianne Jorgensen 
dan Louise Phillips, bahwa konstruksionisme sosial dibangun atas beberapa premis, yakni 1) Pendekatan kritis terhadap pengetahuan yang taken for granted; 2) Spesifikasi kultural dan historis; 3) Hubungan antara pengetahuan dan proses sosial; 4) Hubungan antara pengetahuan dan tindakan sosial (Marianne Jorgensen dan Louise Phillips, 2002, h. 5$6)$.

\section{PEMBAHASAN}

\section{Pemikiran Yusuf Qardawi}

Istilah ahli dzimah secara mkana mantuq memiliki makna sekelompok orang atau golongan yang melakukan ikatan perjanjian menjadi bagian dari anggota dari suatu masyarakat yang berhak mendapatkan perlindungan (Muhammad Murtada al-Husaini al-Zabidi, 1965, h. 40) dan dalam (Ibnu Manzur, 2003, h. 523). Sedangkan secara makna mafhum, istilah tersebut mengandung makna sebagai pemilik jaminan, pemilik perjanjian dan pemilik tangguhan(Abdul Aziz Dahlan, 2006, h. 202). Makna ini masih berdasarkan sudut pandang ilmu figh. Yususf Qardawi dalam kasus ini membatasi istilah tersebut dalam makna sebuah perjanjian, upaya penjaminan dan penciptaan keamanan. Hal tersebut diyakini karena adanya jaminan dari Alloh dan Rosul-Nya serta legitimasi dari konsensus masyarakat, baik secara politis maupun secara hukum. Dengan demikian, warga negara asing yang telah mendpatkan kewarganegaraan berhak memperoleh hak dan terikat pada hak dan kewajiban berdasarkan konsesnsus negara tersebut (Yusuf Qardawi, 1994, h. 18-19).

Pendapat tersebut diperkuat dengan pendapatnya Jonathan, bahwa istilah tersebut merupakan sekelompok nonMuslim yang tinggal diwilayah pemerintahan Muslim. Untuk memperjelas makna tersebut, Sayyid Sabiq membatasi dengan kata muahad, yang berarti nonMuslim melakukan perjanjian dengan orang Islam, baik itu perjanjian dengan cara genjatan senjata, permohohan jaminan keamanan yang ditetapkan oleh pmerintah Muslim berdasarkan kesepakatan atau kontrak (Sayyid Sabiq, 2007, h. 48).

Sedangkan pandangan yang berbeda dari batasan makna di atas, bahwa istilah tersebut memiliki makna sebagai ahli kitab yang telah dewasa, tamyis, merdeka dan mampu berperang (Hamid, n.d., h. 198). Pendapat ini sama dengan pendapat yang diungkapkan oleh Ibnu al-Juza'I bahwa $a h l$ dzimah memiliki arti sebagai non muslim yang merdeka, baligh dan tamyiz (Muhammad ibn Ahmad ibn al-Juza'i alKalabi, n.d., h. 184).

Terjadinya perbedaan pemaknaan istilah ahl dzimah tersebut disebabkan kata trsebut memiliki makna musyarakah atau lebih dari satu, bisa juga disebabkan pengambailan sudut pandang yang berbeda terhadap makna tersebut. Pemaknaan terhadap istilah tersebut dapat dilihat dari makna mazas, makna haqiqi, makna 'urf dan makna syar'i. Jika kita tarik makna yang telah disebutkan di atas, kebanyakan mereka membahasa makna ahl dzimah berdasarkan makna 'urf dan syar'i. Sehingga dapat diketahui sudut pandang pemaknaan yang digunakan oleh Yususf Qardawi terhadap istilah Ahl Dzimah berdasarkan pada makna syar'I atau pendekatan makna fiqh.

\section{Eksistensi Ahl Dzimah}

Setelah makna istilah ahl dzimah terjawab, pertanyaan selanjutnya yang memerlukan jawaban yaitu bagaimana eksistensi ahl dzimah dalam masyarakat?. Komunitas minoritas dalam mayoritas jika tidak diatur hak dan kewajibanyya akan menimbulkan konflik yang berkepanjangan. Maka upaya dalam mengurai permasalah tersebut perlu ditentukan sebuah aturan yang bersifat mengikat dan dijadikan pijakan dalam bermasyarakat. Perjanjian yang bermura 
pada jaminan untuk mendapatkan hak dan kewajiban sebagai bagian dari warga negara islam yang dilindungi. Secara umum hak dan kewajiban tersebut sama dengan yang diperoleh oleh kaum Muslim, hanya berbeda dalam masalah keamanan negara saja mereka mempunyai hak sedikit terbatasi.

Sebenarnya, penyebutan ahl dzimmah tersebut memberikan isyarat bahwa mereka (non-Muslim) mendapatkan jaminan dari Allah, Rasul-Nya, dan kaum Muslim untuk dapat hidup dan memiliki ikatan di bawah naungan Islam dengan aman dan damai, mereka ini yang dalam istilah sekarang berstatus warga negara dalam suatu negara Islam (Yusuf Qardawi, 1997, h. 292). Selanjutnya, mereka yang telah mendapatkan jaminan tersebut harus dilindungi dan diperlakukan sesuai dengan perjanjian yang telah disepakati. Seorang ahli fikih, Maliki Syihabudin al-Qarafi menyinggung masalah tanggung jawab umat dan negara terhadap ahl dzimmah ini dengan mengatakan:

"Perjanjian perlindungan adalah menentukan hak yang harus kita patuhi, karena sesungguhnya mereka itu ada di samping kita, dalam perlindungan kita, dalam perjanjian kita, dalam perjanjian Allah, dalam perjanjian Rasulullah Saw dan dalam perjanjian Islam. Oleh karena itu, barang siapa yang mengganggu mereka kendati dengan sepatah kata yang tidak baik, atau dengan mengumpat yang menodai kehormatan mereka, atau dengan gangguan apapun, maka sungguh ia (yang menganiaya tersebut) telah mengenyampingkan perjanjian Allah, Perjanjian Rasulullah Saw, dan perjanjian Islam (Yusuf Qardawi, 1997, h. 293)".

Menurut pandangan Yusuf alQaradhawi, dasar pertama dalam perlakuan terhadap Ahl Dzimmah ialah bahwa mereka memiliki hak-hak yang sama seperti dimiliki kaum Muslimin kecuali dalam beberapa hal tertentu, sebagaimana mereka dibebani kewajiban-kewajiban yang sama seperti yang dibebankan atas kaum Muslimin kecuali dalam beberapa hal tertentu.

Secara personal individu, ahl adzhimmah memiliki hak yang sama secara kedudukan di dalam kebersamaan hidup di tengah-tengah masyarakat. Mulai hal-hal yang meliputi secara prifasi dan secara luasnya dalam bermasyarakat. Adapun hak tersebut yang diimbangi dengan adanya nilai-nilai kebersamaan untuk dapat bersandingan antara mayoritas dan minoritas. Personalnya hak ahl adzhimmah ialah seperti;

\section{Hak Mendapatkan Kebebasan}

Diantara hak-hak ahl dzimmah yang dijaga dan dilindungi oleh Islam ialah hak kebebasan. Yang terpenting diantaranya ialah kebebasan beragama dan beribadah (Yusuf Qardawi, 1994, h. 42). Setiap orang berhak dan berwenang dalam memeluk agama dan kepercayaannya masing-masing. Tidak boleh dipaksa untuk meninggalkan ataupun dilakukan penekatan dengan cara apapun aagar berpindah ke agama Islam. Piagam Madinah sudah membuktikan bahwa Islam adalah agama yang sangat toleran dengan agama lain. Kemudian kedepannya Yusuf al-Qaradhawi membagi hak kebebasan yang dimiliki oleh ahl dzimmah sebagai berikut:

\section{Hak Kebebasan Beragama}

Diantara hak-hak Ahl Dzimmah yang dijaga dan dilindungi oleh Islam ialah hak kebebasan. Yang terpenting diantaranya ialah kebebasan beragama dan beribadah. Setiap orang berhak memeluk agama dan keyakinannya masing-masing. Tidak boleh dipaksa untuk meninggalkan ataupun dilakukan dengan cara apapun agar berpindah ke agama Islam. Landasan hak ini ialah Firman Allah Swt dalam Q.S. al- 
Baqarah/2: 256: Artinya: "Tidak ada paksaan untuk (memasuki) agama (Islam), sesungguhnya telah jelas jalan yang benar daripada jalan yang sesat. Karena itu, barang siapa yang ingkar terhadap Thaghut dan beriman kepada Allah, maka sesungguhnya ia telah berpegang dengan tali yang sangat kuat, yang tidak akan putus. Dan Allah Maha Mendengar lagi Maha Mengetahui”. (Q.S. al- Baqarah/2: 256) dalam (Departemen Agama RI, 2002).

Yusuf al-Qaradhawi mengutip pendapat ulama tafsir, Ibnu Katsir berkata: "Jangan memaksa siapapun untuk memeluk agama Islam. Sebab sudah cukup jelas petunjuk-petunjuk dan bukti-buktinya, sehingga tidak perlu ada pemaksaan terhadap seseorang untuk memasukinya".

Ahmad Syalabi dalam bukunya yang berjudul muqaranat al-adyan, mengutip salah satu ucapan sejarawan Barat yang mengatakan, "Sebenarnya banyak bangsa yang tidak mengenal adanya penakluk yang penuh cinta kasih dan sangat bertenggang rasa seperti bangsa Arab. Begitu pula tidak ada agama yang sangat toleran seperti agama mereka (Muhammad as-Sayyid Yusuf dan Ahmad Durrah, n.d.). Sejarawan Barat lainnya yang dikutip dalam buku yang sama mengatakan dalam bukunya "Sejarah Bangsa Islam (Tharik asySyu "ubb al-Islamiyyah)", sebagai berikut, "Suatu kekeliruan bila kita menganggap Islam tidak menganut prinsip toleransi politik. Sejarahnya lebih baik dibanding sejarah agama Masehi (Kristen atau Katolik).

Muhammad al-Ghazali juga menyebutkan, ketika terjadi peperangan antara umat Islam dengan umat Kristen, Islam tidak memandangnya sebagai perang dua agama, tetapi menyebutnya sebagai perang antara dua Negara. Ketika Islam memenangkan peperanagan tersebut, tidak ada larangan bagi umat Kristen untuk masuk dan beribadat di dalam gereja mereka. Islam tidak membuat peraturan seperti peraturan yang dibuat oleh gereja yang menghukum mati setiap orang yang berbeda keyakinan dengan gereja (Muhammad al-Ghazali, 1980, h. 96). Salah satu bentuk toleransi Islam terhadap agama lain adalah larangan Islam terhadap pengikutnya untuk mencela agama lain, sebagaimana Firman Allah Swt dalam Q.S. al-An'am/6: 108;

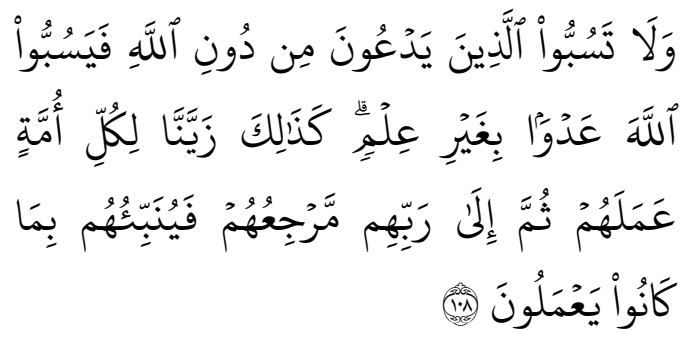

Artinya: "Dan janganlah kamu memaki sembahan-sembahan yang mereka sembah selain Allah, karena mereka nanti akan memaki Allah dengan melampaui batas tanpa pengetahuan.” (Q.S. al-An'am/6: 108) dalam (Departemen Agama RI, 2002).

Sebagai upaya yang dilakukan dalam merelevansikan penafsiran dengan kondisi zaman amatlah perlu menjadi perhatian yang khusus. Dikarenakan akan lahirnya kajian dan pemikiran perkembangan hukum-hukum syariat dan ketentuan dalam Islam menjadi barang baru dan perlunya ada upaya penjabaran dan pengejawentahan kepada khalayak luas (Hafizah, 2021, h. 19).

Para ahli tafsir menyebutkan bahwa sebab turun ayat ini adalah orang-orang Muslim mencela patung sembahan orang musyrik, maka orang musyrik membalas dengan mencela Allah karena memusuhi orang Islam (Thantawi, n.d., h. 152). Ayat di atas menimbulkan pertanyaan penting, kenapa umat Islam dilarang mencela patung sembahan orang kafir? Sebagian ulama memberikan alasan atas larangan ini, diantaranya: 1) patung tersebut adalah benda mati dan tidak ada dosa. 2) Mencela 
tuhan orang kafir akan menyebabkan kemaksiatan (adanya penghinaan terhadap Allah), sedangkan yang wajib bagi umat Islam adalah menjelaskan kesalahan mereka dengan bijaksana, bukan dengan hinaan. 3) Mencela sembahan orang kafir akan menyebabkan kemudharatan yang lebih besar, karena hal ini hanya akan menimbulkan kemarahan mereka yang menyebabkan mereka semakin menjauh dari ajaran Islam (Thantawi, n.d., ibid, h. 153).

Imam al-Qurthubi mengatakan bahwa ayat ini tetap berlaku dan tidak ada yang menasyakhnya (merubah hukumnya). Maka setiap orang Muslim tidak dibolehkan mencela agama mereka, tempat ibadah mereka, salib-salib mereka, dan perbuatan lain yang menyebabkan mereka mencela agama Islam. Hal ini dikarenakan yang demikian itu akan menimbulkan kemaksiatan dan perpecahan yang besar dalam kalangan yang lebih umum dan kompleks (Ahmad, 2005, jilid VII, h. 45).

Dimasa pemerintahan Umar Ibnu Khattab, ia menulis surat tentang kebebasan beragama bagi penduduk iliya (Palestina), "Inilah yang diberikan Umar, pemimpin orang-orang muslim kepada penduduk iliya, aku memberikan jaminan keamanan terhadap diri mereka, harta benda, gereja, salib dan semua yang berhubungan dngan agama mereka, gereja mereka tidak boleh diambil alih, tidak boleh dihancurkan atau pun diperkecil. Dan mereka tidak akan dipaksa dengan agama mereka, dan tidak akan ada yang disakiti seorangpun dari mereka (Jarir, 1995, Jilid. 3, h. 609).

Bahkan Abu Yusuf, dalam kitabnya al kharraj meriwayatkan bahwa Khalid Ibnu Walid memberikan izin kepada penduduk $A$ "nat untuk membunyikan lonceng diwaktu apapun, kecuali waktu shalat, dan mereka juga dipersilahkan mengeluarkan salib dan lambang keagamaan di hari raya mereka. Meskipun Islam memberikan kebebasan yang sangat luas bagi ahl dzimmah, Islam meminta kepada mereka untuk tetap menghormati perasaan umat Islam dan kemuliaan agama mereka. Oleh karena itu, mereka dilarang untuk menampakkan salib dan siyar agama mereka (selain hari raya mereka) didaerah yang mayoritasnya umat Islam. Mereka juga dilarang membangun gereja di tempat tersebut.

Berkaitan dengan prihal tersebut, maka dalam pandangan dan argumentasi yang diungkapkan oleh Qaradhawi, pembangunan gereja tersebut akan menyakitkan perasaan umat Islam dan akan membawa kepada fitnah serta kekacawan. Namun al-Qaradhawi juga menyebutkan, bahwa sebagian ulama juga ada yang memiliki pendapat yang berbeda dengan dirinya. Mereka berpendapat, bahwa pembangunan gereja atau tempattempat ibadah agama selain Islam tetap diperbolehkan apabila Imam mengizinkan pembangunan tersebut, karena kemaslahatan yang diperhatikan Islam (Yusuf Qardawi, 1994, h. 20-21) dalam Muhammad Zaini (Hak dan Kewajiban ahl Adzimmah Menurut Yusuf Qardhawi).

Yusuf al-Qaradhawi tetap memberikan hak yang sesuai dengan kebutuhan ahl dzimmah. Apabila sebuah tempat banyak non-Muslim yang tinggal disana, dan kebutuhan mereka terhadap tempat ibadah sangat besar, maka mereka dipersilahkan untuk membangun tempat ibadah, dengan tetap memperhatikan perasaan umat Islam disana, seperti besar bangunannya hanya sesuai dengan kebutuhan, tidak lebih besar dari masjid, dan harus mendapat izin dari penguasa Muslim. Namun, jika nonMuslim yang tinggal disana hanya sedikit, maka tidak dibenarkan membangun tempat ibadah tersebut.

Dapat disimpulkan bahwa toleransi terhadap para penganut agama lain, seperti 
dipraktekkan oleh kaum Muslimin yang hidup mereka sepenuhnya berlandaskan agama dan disaat mereka telah meraih kemenangan kekuasaan sempurna, adalah sesuatu yang belum pernah dikenal dalam sejarah agama-agama lain.

Dan Islam di dalam ajarannya selalu memberikan pemahaman dan penerangan akan penguatan dan penegakan aqidah secara kaffah. Bahkan diutamakan setiap individu dalam Islam untuk memiliki nilai dan karakter. Dalam best practice character building yang diungkap Erie Sudewo bahwasanya sebuah peradaban akan mengalami ketidak pastian dan kegoncangan dengan salah satu diakibatkan tidak adanya karakter (Hidayat, 2019, h. 2).

\section{Hak Kebebasan untuk Bekerja}

Orang-orang yang non-Muslim memiliki kebebasan untuk bekerja dan melakukan usaha, baik bersangkutan dengan orang-orang selain mereka ataupun bekerja sendiri, memilih pekerjaanpekerjaan bebas yang mereka inginkan serta mengelola berbagai macam kegiatan ekonomi, sama seperti kebebasan yang dimiliki kaum Muslimin, namun ada batasan-batasannya sama seperti kaum Muslimin (Yusuf Qardawi, 1994, Terj. Muhammad Baqir, h. 50).

Yusuf al-Qaradhawi mengatakan, sesungguhnya ahl dzimmah dalam jual beli, perdagangan dan segala macam transaksi keuangan, sama seperti kaum Muslimin. Namun mereka juga diharamkan melakukan transaksi riba, sebagaimana diharamkan kepada orang Muslim. Mengenai hal ini, telah diriwayatkan bahwa Nabi Muhammad Saw pernah menulis surat kepada kaum Majusi dari Hajar "Hendaknya kalian meninggalkan riba atau, jika tidak, bersiaplah untuk menerima pernyataan perang dari Allah dan Rasul-Nya". Demikian pula mereka ahl dzimmah tidak boleh menjual khamr dan babi di daerahdaerah kediaman kaum Muslimin atau membuka kedai-kedai minuman yang menyediakan khamr dan memudahkan peredaran serta pemasukannya kedalam daerah-daerah kediaman kaum Muslimin secara terbuka dan terang-terangan, walaupun hal itu untuk konsumsi mereka sendiri. Larangan seperti ini dimaksudkan untuk mencegah kerusakan akhlak dan menutup pintu dekadendi moral.

Selain hal tersebut, ahl dzimmah dapat menikmati kebebasan penuh dalam perdagangan, industri dan keterampilan. Demikian itu telah berlangsung dalam praktek dan disaksikkan oleh sejarah kaum Muslimin sepanjang masa. Bahkan beberapa macam pekerjaan dan keterampilan hampir-hampir dimonopoli oleh mereka seperti kegiatan perbankan (penukaran mata uang), farmasi dan lainlain. Hal tersebut berlangsung terus sampai waktu-waktu belakangan dibanyak Negara Muslim. Dari hasil kegiatan-kegiatan itu mereka berhasil mengumpulkan kekayaan yang luar biasa besarnya, bebas dari zakat dan pajak apapun selain jizyah, yaitu pajak yang jumlahnya sangat sedikit atas pribadipribadi yang mampu mengangkat senjata (Yusuf Qardawi, 1994, ibid, h. 52).

\section{Hak dalam Mendapatkan Jabatan Pemerintahan (Politik)}

Ahl dzimmah memiliki hak untuk menduduki dan mengemban jabatanjabatan dalam pemerintahan seperti halnya kaum mayoritas dalam kehidupan bermasyarakat. Dicontohkan seperti memimpin negara, panglima keamanan, hakim dan penanggungjawab segala macam urusan yang disesuaikan dengan ketentun yang ada dalam syariat seperti halnya zakat dan sedekah (termasuk wakaf dan sebagainnya) bagi kaum Muslim.

Sebab ahl dzimmah tidak diperbolehkan memegang jabatan ini karena jabatan tersebut sangat berkaitan 
dengan akidah Islam. Jabatan keimaman menurut al-Qaradhawi, adalah sebuah jabatan kepemimpinan umum dibidang agama dan dunia sekaligus, yakni menggantikan posisi Nabi Muhammad Saw, sehingga sangat tidak mungkin jabatan tersebut dipegang oleh nonMuslim, dan tidaklah masuk akal bahwa seseorang akan melaksanakan hukumhukum Islam dan memeliharanya dengan baik kecuali ia seorang Muslim. Adapun jabatan kepemimpinan atas angkatan bersenjata bukanlah urusan yang sematamata bersifat bebas, tapi itu adalah kegiatan ibadah dalam Islam, karena perang membela agama dan negara dalam pandangan Islam adalah jihad, sehingga jabatan ini sangat tidak layak dipegang oleh non-Muslim, sebab jihad merupakan puncak ibadah dalam Islam.

Peradilan adalah penerapan hukum Syariat Islam, sedangkan seorang nonMuslim tidak mungkin dituntut agar menerapkan suatu hokum yang ia sendiri tidak percaya kepadanya. Demikian juga urusan zakat, sangat jelas bahwa ini harus dipegang oleh orang Islam, karena masalah ini adalah masalah keagamaan di dalam agama Islam. Tugas-tugas pemerintahan di luar bidang-bidang tersebut boleh diserahkan kepada ahl dzimmah apabila terpenuhi persyaratan-persyaratanya pada diri mereka seperti kecakapan, kejujuran dan kesetiaan kepada Negara. Tentunya mereka itu harus tidak termasuk orangorang yang memendam rasa dengki dan benci terhadap kaum Muslimin (Yusuf Qardawi, 1994, ibid, h. 54).

Demikian tingginya toleransi kaum Muslimin sehingga beberapa dari para fuqaha berpandangan seperti al-Mawardi menyatakan dalam bukunya, Al-Ahkam AsSulthaniyah terkait tentang diperbolehkannya orang-orang dzimmi menduduki jabatan Kementrian pelaksanaan (Wizarah Tanfidz), yang dimaksud dengan menteri pelaksanaan ialah seorang yang meneruskan perintahperintah dan keputusan-keputusan Imam serta pelaksanaannya. Bahkan, dalam realitanya jabatan-jabatan strategis di masa itu banyak dipegang oleh ahl dzimmah, sehingga banyak orang Islam yang mengeluhkan hal itu, seakan-akan mereka dikuasai oleh non-Muslim. Dan yang dicatat oleh sejarah Islam, ketika Daulah Utsmaniah berkuasa, mereka lebih banyak mempercayakan jabatan-jabatan penting kepada orang non-Muslim, bahkan sebagian besar duta-duta berasal dari orang Nasrani, sementara mereka itu sama sekali tidak peduli akan keruntuhan pemerintahan yang mereka wakili.

\section{Dasar Pemikiran Yusuf Qardhawi Terhadap Partisipasi Muslim dalam Pemerintahan Non Muslim}

Hubungan harmonis adalah merupakan sebuah cita-cita yang diidamkan dalam hidup berdampingan dengan satu atau berlainan keyakinan dan keimanan. Karena hal ini didasari atas nilai dalam Islam, seperti yang termaktub dalam kalimat rahmatan lil a'alamin. Konteks ini dalam ajaran agama Islam menjadi sebuah kunci jawaban dalam hidup dalam segala lini untuk bersama dan berdampingan. Tak ubahnya ketika pemikiran tersebuh terakomodir dalam sebuah wadah yang dimana ulama dapat menjelaskan secara ringkas dan rinci terkait berbagai syariat ajaran agama Islam. Karena setiap ulama mempunyai metode tersendiri dan cara-cara dalam memahami, menafsirkan dan menjelaskan teks Al-Qur'an secara terang dan dijelaskan kembali dalam Hadis Nabi. Itulah salah satu penyebab banyak ditemukannya perbedaan pendapat antara ulama yang satu dengan yang lain.

Sumber hukum inti dari umat Muslim ialah Al-Qur'an dan Hadis. Dan ini adalah tuntunan bagi umat Islam di dalam 
menyikapi berbagai perbedaan dan permasalahan-permasalahan umat Muslim, baik hubungan antara sesama Muslim atau dengan non-muslim. Pola, model dan corak yang dijelaskan Qardhawi dalam pemikirannya selama ini ialah dengan menjadikan sebuah posisi poros tengah untuk merangkul dan menjembatani ketegangan atas dasar pemikiran yang saling bersebrangan. Ciri yang dijabarkan dalam pemikiran Qardhawi merupakan dasar di dalam ia mengambil semua kesimpulan dalam fatwanya, seperti;

Menjauhkan setiap individu dalam kejumudan memaknai kandungan AlQur'an dan Hadis, Sekaligus tidak Terlalu Bebas dalam Memahaminya.

Al-Qardhawi merupakan salah satu ulama Muslim yang pemikirannya memberikan kontribusi yang sangat besar bagi perkembangan umat Islam. Pemikirannya bisa diterima oleh kebanyakan umat Muslim karena pemikirannya selalu mengedepankan kemaslahatan dan menajuhi sifat berfikir yang jumud di dalam memandang kandungan Al-Qur'an dan Hadis Nabi. AlQardhawi juga selalu berusaha mencari jalan tengah dalam upaya memahami dan menjelaskan kandungan Al-Qur'an serta yang terkandung di dalam Hadis. AlQardhawi tidak terpaku dengan teks tersebut seperti kebanyakan ulama konserpatif, namun juga tidak berlebihan dalam memahami konteks Al-Qur'an dan hadis sebagaimana yang sering dilakukan oleh para pemikir liberal, sehingga pendapatnya selalu berada di tengah-tengah yang sering disebut dengan istilah "attayyar al-washatiah".

\section{Berpegang Pada Ulama Terdahulu}

Al-Qardhawi selalu mengutamakan maslahat dalam pendapatnya meskipun harus berbenturan dengan pendapat jumhur ulama. Namun Qaradhawi masih bisa mempertanggung jawabkan pendapatnya dan tetap berusaha mengambil pendapat salah satu dari ulama terdahulu. Yang melahirkan sebuah fatwa dan dijadikan dasar atau jumhur ulama dengan pendapat bahwa orang Islam yang membunuh orang kafir (harbi atau dzimmi) tidak boleh diqishah (dihukum mati), ia cuma diwajibkan bayar diat. Akan tetapi Qaradhawi mempunyai pendapat lain, menurutnya yang tidak boleh dihukum mati dalam masalah ini adalah orang yang membunuh kafir harbi, sedangkan orang yang membunuh kafir zdimmi diperbolehkan untuk dihukum mati. Meskipun berbeda dengan pendapat jumhur ulama, Qardhawi mengatakan bahwa pendapat ini juga pernah dibawakan oleh Abu Hanifah.

\section{Fokus Terhadap Fikih Prioritas}

Qaradhawi menitik beratkan keutamaan urutan amal menjadi pendahulu di dalam kajian fiqih prioritasnya. Sehingganya, sebuah hal yang tidak dirasa cukup penting tidak menjadi sekala utama dalam perkara dan hal-hal yang penting.

Dan seterusnya berbagai hal penting bukan didahulukan atas prihal yang lebih atau sangat penting. Selanjutnya, berbagai perkara yang tidak kuat (marjuh) tidak diurutkan terlebih dahulu dari prihal yang kuat (rajih). Kemudian prihal yang biasa saja, bukan kadar pendahuluan atas pelbagai prihal yang utama dan atau paling utama. Dan intinya ialah hal-hal yang seharusnya dijadikan sekala prioritas dan didahulukan harus segera didahulukan dan sebaliknya yang akhir untuk segera diakhirkan. Yang sangat menelisik ialah prihal dan masalah kecil jangan dibesarkan serta diabaikan begitupun prihal besar janganlah dianggap semua angin semu dan artinya untuk segera dicarikan jalan keluarnya.

Oleh sebabnya, perkara dan masalah tersebut pada intinya haruslah diletakkan 
dan didasarkan pada tempatnya dengan bijak, cukup dan imbang.

\section{Kemaslahatan Hal Utama dari Pada Jumhur Ulama}

Qardhawi merupakan ulama yang bergelut dalam menyikapi permasalahanpermasalahan umat yang muncul dizaman sekarang. Dengan berbagai perhatian dan pendapat yang berargumentasi dilahirkannya dan merupakan pendeskripsian berbagai permasalahan yang muncul di tengah-tengah umat. Kemaslahatan dimasa sekarang menurutnya lebih penting dari pada mengikuti kebanyakan pendapat ulama terdahulu. Ketika sebuah pembahasan yang dimasa lalu hampir seluruh ulama sepakat, namun ketika dimasa sekarang menurutnya tidak relevan lagi, maka al-Qaradhawi akan mengambil pendapat salah satu ulama yang berbeda dengan kebanyakan ulama lainnya, asalkan pendapat tersebut menurutnya sesuai untuk jaman sekarang. Ini terlihat jelas ketika al-Qaradhawi mengambil pendapat sebagian ulama Hanafiah dalam kasus pembunuhan kafir dzimmi. Salah satu bukti bahwa al-Qaradhawi akan mengenyampingkan pendapat kebanyakan ulama, apabila menurutnya sudah tidak sesuai dengan kenyataan yang ada, yaitu pendapatnya tentang hadis.

Upaya di dalam menengahi perdebatan tersebut Qardhawi memberikan dasar-dasar sebagai bentuk manifestasi keseragaman bila ditimbang dari kemaslahatan bagi umat secara luas. Mempertahankan hak dan kewajiban menjadi bentuk interpretasi bagaimana keimanan seorang Muslim pada Tuhan dan pemimpinnya. Walau dalam ajaran Islam seorang pemimpin ialah harusnya Muslim, namum jumhur ulama tersebut dalam menyikapi keadaan kondisi mayoritasnya berada dimana seorang Muslim menjadi kajian tersendiri (minoritas). Seperti membahas hak-hak ahladzhimah dan kewajibanya sebagai aplikasi dan ajaran sikap mendemonstrasikan nilainilai syariat Islam.

Berstatus ahl-adzhimah bagi kalangan Muslim di dalam mayoritas nonmuslim menjadikan ini sebagai nilai fundamental yang sangat elok dalam menengahi masalah yang menengarai dipermukaan. Adapun hak-hak tersebut ternilai dalam sikap dan dasar pemikiran yang Qardhawi fatwakan, seperti;

\section{Hak dalam Mendapatkan Perlindungan dan Keamanan}

Hak mendapatkan perlindungan adalah hak pertama yang harus dimiliki oleh ahl dzimmah ketika berada di bawah naungan negara Islam dan masyarakat Islami. Perlindungan ini meliputi perlindungan terhadap segala macam pelanggaran (serangan) yang berasal dari luar negeri maupun terhadap segala macam kezaliman yang berasal dari dalam negeri, sedemikian sehingga mereka bener-bener menikmati rasa aman dan tentram (Yusuf Qardawi, 1994, ibid, h. 21-22). Tidak hanya itu, mereka harus mendapatkan perlindungan nyawa, jiwa dan raga, perlindungan terhadap harta benda atau kekayaan yang dimiliki, perlindungan terhadap kehormatan dari serangan dan intimidasi kelompok mayoritas untuk tidak dideskriminasi dan mendapatkan jaminan hari tua dan jaminan kemiskinan.

Perlindungan ini tidak mungkin bisa terwujud tanpa adanya jaminan yang pasti dari syariat Islam. Yang kemudian Yusuf Qaradhawi membagi hak perlindungan yang dimiliki oleh ahl dzimmah menjadi beberapa bagian:

\section{Hak Perlindungan Terhadap Pelanggaran} Dari Luar Negari

Mengenai perlindungan terhadap pelanggaran yang berasal dari luar negeri, mereka memiliki hak yang sama seperti yang dimiliki kaum Muslimin. Kewajiban seorang Imam atau Waliyul Amri dari kalangan Muslimin untuk 
menyelenggarakan perlindungan seperti ini dengan kekuasaan yang dilimpahkan kepadanya oleh syariat serta kekuatan militer yang berada di bawah wewenagnya.

Dalam kitab Mathalib Ulin Nuba (salah satu kitab dalam mazhab Imam Hambali) disebutkan "seorang Imam wajib menjaga keselamatan ahl dzimmah dan mencegah siapasaja yang mengganggu mereka, melepaskan mereka dari tindakan penawanan dan menolak kejahatan siapa saja yang hendak menunjukan kepada mereka. Hal ini berlaku selama mereka berdiam di negeri Darul Islam.

Menurut Yusuf al-Qaradhawi, mengutip dalam bukunya al-Faruq Imam Qarafi al-Maliki menukilkan ucapan Ibn Hazm dalam bukunya Maratib al- Ijma", "Apabila kaum kafir datang ke negeri kita karena hendak mengganggu orang yang berada dalam perlindungan akad dzimmah maka wajib atas kita menghadang dan memerangi mereka dengan segala kekuatan dan senjata, bahkan kita siap mati untuk itu demi menjaga keselamatan orang yang berada dalam dzimmah Allah Swt dan Rasul-Nya Saw. Menyerahkannya kepada mereka tanpa upaya-upaya tersebut dianggap menyia-nyiakan akad dzimmah. Ketika ahl dzimmah mendapatkan ancaman atau berupa tekanan dari luar, maka syariat Islam mewajibkan kepada negaranya untuk mengantisipasi serta menetralisir ancaman tersebut (Yusuf Qardawi, 1994, ibid, 23).

Diantara sikap-sikap penerapan konsep Islami ini ialah seperti yang pernah diriwayatkan dari Syaikhul Islam Ibnu Taimiyah. Ketika orang-orang Tar-tar menguasai negeri Syam, Ibnu Taimiyah pergi menemui Qathlu Syah agar melepaskan para tawanan. Panglima pasukan Tar-tar itu mengizinkan pelepasan para tawanan dari kalangan ahl dzimmah. Segera Ibnu Taimiyah berkata kepadanya: "Kami tidak akan merasakan puas kecuali dengan pelepasan seluruh tawanan, termasuk kaum Yahudi dan Nasrani karena mereka adalah orang-orang terikat kepada dzimmah kami. Oleh sebab itu, kami tidak akan membiarkan tetap tertawannya ahl dzimmah ataupun ahl millah (yakni kaum Muslimin). Akhirnya, karena melihat ketetapan hati Ibnu Taimiyah, panglima tersebut melepaskan semua tawanan (Yusuf Qardawi, 1994, ibid, h. 24).

\section{Hak Perlindungan Terhadap Kezaliman di Dalam Negeri}

Perlindungan terhadap kezaliman yang berasal dari dalam negeri adalah sesuatu yang diwajibkan oleh Islam, bahkan sangat diwajibkan. Islam memperingatkan kaum Muslimin agar jangan sekali-kali mengganggu dan melanggar hak ahl dzimmah, baik dengan tindakan ataupun ucapan. Sedangkan Allah Swt tidak menyukai orang-orang zalim dan tidak pula memberi mereka petunjuk. Sebaliknya, ia akan menyegerakan azab atas mereka atau menagguhkan hukuman atas mereka di akhirat secara berlipat ganda (Yusuf Qardawi, 1994, ibid, h. 24-25).

Amat banyak ayat-ayat dan haditshadits yang secra umum mengharamkan kezaliman dan mencelanya dengan keras serta mengingatkan akan akibatnya yang sangat buruk diakhirat maupun di dunia. Dalam sebuah hadis qudsi Allah berfirman yang artinya:

"Dari Abu Dzar al-Ghifari
Radhiyallahu anhu bahwa Nabi
Shallallahu alaihi wa sallam
meriwayatkan Firman Allah Azza wa-
Jalla, "Wahai hamba-Ku!

Sesungguhnya Aku mengharamkan kezhaliman atas diri-Ku dan Aku menjadikannya haram di antara kalian. Maka, janganlah kalian saling menzhalimi (Imam Muslim, 2000, Jilid IV, h. 1994).

Dari hadis qudsi tersebut bisa dipastikan bahwa Islam adalah agama yang anti kezaliman. Selain hadis tersebut sangat 
banyak ayat-ayat Al-Quran dan hadis Nabi yang mengharamkan kezaliman, dan memberikan ancaman yang keras terhadap pelakunya. Sehingga ditarik kesimpulan ajaran manapun yang mengatasnamakan agama Islam, namun masih terdapat rasa ketidak adilan dan kezaliman, ajaran tersebut diyakini bukan bersumbar dari Islam.

Menurut al-Qaradhawi, ketika nonMuslim berada di bawah naungan negara Muslim, mereka sudah dipastikan mendapatkan jaminan keamanan dari ganguan manapun, bahkan dari gangguan orang Islam sendiri. Secara khusus banyak hadis Nabi dan perkataan para sahabat yang menyatakan bahwa keamanan mereka sudah dijamin oleh Allah dan rasulnya.

Berikut hadis yang menjamin keamanan mereka: Artinya: "Ingatlah, siapa yang sewenang-wenang terhadap orang yang terikat perjanjian, merendahkannya, membebaninya di atas kemampuannya atau mengambil sesuatu darinya tanpa kerelaan darinya (merampas), maka aku adalah lawan bertikainya pada Hari Kiamat. (HR Abu Dawud) dalam (Imam as-Shayuthi, 1999, Jilid 2, h. 158).

Dan Nabi dalam Sabda-nya kembali: "Barang siapa yang membunuh orang yang terikat perjanjian, maka dia tidak akan mencium bau surga, sungguh bau surga itu tercium dari jarak perjalanan 40 tahun" (HR al-Bukhari) (Imam Baihaki, 1984, Jilid IX, h. 205).

Di dalam kekhalifahan Umar ibnu alKhattab sering bertanya kepada orang yang datang dari daerah serta mempertanyakan kondisi ahl dzimmah. Hal tersebut karena khawatir yang ada dari diri kaum Muslimin akan timbulnya gangguan terhadap mereka. Merekapun menjelaskan dengan sejelasjelasnya dengan kalimat "tiadalah sesuatu yang kami ketahui terlain sebuah perjanjian yang dengan sebaik-baiknya".
Ali bin Abi Thalib r.a pernah berkata: "ahl dzimmah membayar jizyah agar harta mereka sama seperti harta kita dan nyawa mereka seperti nyawa kita (yakni memperoleh jaminan penuh) (Al-Mughni, n.d., Jilid VII, h. 111).

Dari kumpulan hadis dan perhatian para sahabat terhadap ahl dzimmah, Para fuqaha (ahli-ahli fikih) dari seluruh mazhab menegaskan bahwa kaum Muslimin wajib mencegah kezaliman apapun yang menimpa ahl dzimmah serta memelihara keselamatan mereka. Bahkan Ibnu Abidin dalam bukunya Hasyiya menyatakan, bahwa berbuat zalim kepada ahl dzimmah lebih besar dosanya dari pada berbuat zalim kepada sesama Muslim (Yusuf Qardawi, 1994, ibid, dalam Muhammad Zaini, "hak dan kewajiban ahl adzimmah menurut yusuf qardhawi). Hal itu mengingat bahwa seorang dzimmi dalam Negara Islam biasanya lebih lemah kedudukannya, sedangkan kezaliman yang dilakukan oleh orang yang lebih kuat terhadap orang yang lebih lemah lebih besar dosanya.

\section{Hak Perlindungan Nyawa dan Badan (kehidupan)}

Hak perlindungan yang ditetapkan bagi ahl dzimmah mencakup perlindungan keselamatan darah, nyawa dan badan mereka sebagaimana mencakup pula seluruh kehidupannya (Yusuf Qardawi, 1994, terj. Muhammad Baqir, Minoritas NonMuslim di dalam Masyarakat Islam, h. 28).

Dalam hadis Nabi Saw bersabda: Artinya:"Dari seorang laki-laki dari kalangan shahabat Nabi shallallaahu ,alaihi wa sallam: Bahwasannya Rasulullah shallallaahu ,, alaihi wa sallam telah bersabda: "Barangsiapa yang membunuh seorang laki-laki dari kalangan ahl dzimmah, niscaya ia tidak akan mencium bau surga. Sesungguhnya bau surga itu dapat tercium dari jarak perjalanan tujuh puluh tahun". (Diriwayatkan oleh An-Nasaeei 8/25 dan 
Ahmad 4/237 dan 5/369 dari jalur AlQasim bin Mukhaimirah, darinya. AsySyaikh Salim Al-Hilaliy berkata: "Sanadnya shahih, kemajhulan seorang shahabat tidaklah merusak keshahihan hadits sebagaimana dijelaskan dalam ilmu Mushthalah Hadits").

Kemudian Baginda Nabi bersabda: Artinya: "Telah menceritakan kepada kami Qais bin Hafsh telah menceritakan kepada kami Abdul Wahid telah menceritakan kepada kami Al-Hasan telah menceritakan kepada kami Mujahid dari Abdullah bin Amru dari Nabi shallallahu 'alaihi wasallam bersabda: "Siapa yang membunuh orang kafir yang telah mengikat perjanjian (mu'ahid) dengan pemerintahan muslimin, ia tak dapat mencium harum surga, padahal harum surga dapat dicium dari jarak empat puluh tahun" (HR. Imam Bukhari, 224).

Dari hadis tersebut sudah jelas adanya jaminan kehidupan khususnya nyawa dan badan dari ahl dzimmah agar dilindungi dalam suatu negara, dan Rasulullah Saw mengancam keras bagi orang yang membunuhnya. Karena itu, kaum fuqaha sepakat bahwa pembunuhan terhadap seorang dzimmi merupakan dosa besar, bahkan termasuk dosa-dosa keji dan besar seperti ancaman keras seperti hadits tersebut. Selebihnya Qaradhawi berpendapat, seseorang yang melakukan pembunuhan boleh dihukum qisash, walaupun banyak kalangan ulama secara mayoritas tidaklah sama pendapatnya (Yusuf Qardawi, 1994, ibid, h. 12).

\section{Hak Perlindungan Keamanan Harta Benda}

Seperti halnya perlindungan terhadap jiwa dan nyawa mereka, demikian pula perlindungan terhadap harta benda mereka. Hal ini merupakan kesepakatan kaum Muslimin dari semua mazhab diseluruh negeri dan pada seluruh masa pemerintahan yang bergantian.
Sesungguhnya ajaran dan syariat Islam merupakan agama fitrah, maka tidak ada satupun prinsip yang bertentangan dengan fitrah atau merusak fitrah itu sendiri. Prinsip-prinsip itu sesuai dengan fitrah, bahkan terkadang meluruskannya dan meningkat bersamanya. Di antara fitrah yang telah Allah ciptakan untuk manusia adalah mencintai hak milik (kepemilikan). Bahkan naluri kepemilikan ini sudah terdapat pada anak-anak, tanpa ada yang mengajari dan menuntun (Yusuf Qardawi, 1994, terj. Muhammad Baqir, Minoritas NonMuslim di dalam Masyarakat Islam, h., 34-35).

Di antara pesan-pesan Umar kepada Abu Ubaidillah ialah: "Cegahlah kaum Muslimin dari bertindak zalim terhadap mereka (yakni ahl dzimmah), mengganggu ataupun memakan harta mereka kecuali dengan cara-cara yang menghalalkannya".

Ali R.a berkata: "Siapa saja mencuri harta milik seorang dzimmi akan dipotong tangannya, siapa merampasnya akan dihukum dan harta itupun akan dikembalikan kepada pemiliknya. Siapa berhutang kepada seorang dzimmi harus melunasinya, dan jika ia dengan sengaja mengulur-ngulur waktu pembayarannya sedangkan ia mampu, maka hakim akan memenjarakannya sampai bersedia membayar hutang itu".

Perhatian dan pemeliharaan Islam terhadap kesucian harta dan milik mereka mencapai kesempurnaan, sedemikian sehingga ia menghormati apasaja yang mereka anggap sebagai harta sesuai dengan agama mereka, meskipun hal itu tidak dianggap sesuatu yang berharga dalam pandangan kaum Muslimin (Yusuf Qardawi, 1994, terj. Muhammad Baqir, ibid, h.36). Karena Islam sangat melindungi harta benda setiap orang, maka disyariatkan hukum pemotongan tangan bagi sipelaku pencurian, jika sudah memenuhi syaratsyarat yang ditentukan. Firman Allah Swt dalam Q.S al-Maidah/5: 38: 


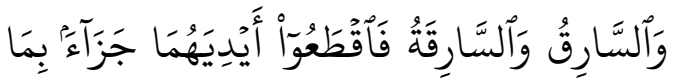

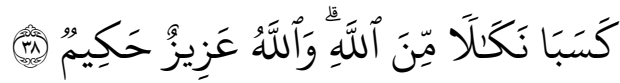

"Dan pencuri laki-laki dan perempuan, potonglah tangan mereka sebagai balasan atas perbuatan mereka". (Q.S. AlMaidah/5: 38).

Dalam sebuah hadis yang diriwayatkan oleh Syaidah Aisyah "bahwa Nabi Muhammad Saw memotong tangan pencuri, ketika nilai curiannya seperempat dinar atau lebih" (Imam Muslim, n.d. Jilid 3, h. 1312 dan Imam an-Nawawi, Shahih, h. 196). Seorang Muslim tidak diperkenankan merampas harta ahl dzimmah, karena tindakan itu jelas-jelas bertentangan dengan prinsip-prinsip Islam yang telah di berlakukan dalam konteks interaksi (pergaulan) dengan orang-orang non-Muslim yang hidup di bawah naungan orang Islam. Dalam kitab al-Furuq Li alImam al-Qaurafi, diceritakan bahwa seorang laki-laki bertanya kepada Ibnu Abbas ra," Kami berpapasan dengan ahl dzimmah. Kemudian kami mengambil sesuatu dari mereka". Ibnu Abbas lalu berkata,"Kalian tidak boleh mengambil sesuatupun dari ahl dzimmah kecuali hal itu didasari kesepakatan antara kalian dengan mereka" (Durrah, 2008, h. 111).

Abu Yusuf dalam kitabnya al-kharraj menyatakan bahwa Abu Bakar ketika menjabat sebagai khalifah menulis surat kepada penduduk Najran, salah satu isi dari surat tersebut yaitu: "Bagi penduduk Najran dan sekitarnya ada jaminan Allah dan Rasulnya untuk agama mereka, harta dan perdagangan serta seluruh yang mereka miliki" (Abu Yusuf Yaequb ibnu Ibrahim, 1979, h. 73).

Menurut al-Qaradhawi mengenai hak perlindungan harta benda ahl dzimmah. Tidak jauh berbeda dari pembahasan sebelumnya, yaitu diharamkan segala bentuk kezaliman terhadap ahl dzimmah. Namun, al-Qaradhawi membahas ini karena mengingat ada perbedaan jenis harta diantara orang Muslim dengan orang nonMuslim. Minuman keras dan binatang babi tidak boleh dimiliki oleh orang Islam, baik untuk dirinya atau diperjual belikan, karena keduanya tidak dikatagurikan harta bagi orang Muslim, dan bagi siapa yang merusak kedua benda tersebut dari orang Islam, maka tidak ada sanksi yang akan dijatuhkan, bahkan orang tersebut mendapatkan pahala, karena melaksanakan amar ma'ruf dan nahi munkar.

Akan tetapi, bila khamr dan babi itu dimiliki oleh seorang non-Muslim, keduanya dianggap harta berharga olehnya. Bahkan mungkin termasuk harta yang paling berharga. Maka seperti yang dinyatakan oleh ahli-ahli fiqh mazhab Hanafi, barang siapa merusak sesuatu dari kedua-duanya milik seorang dzimmi, maka ia harus membayar ganti harganya (Yusuf Qardawi, 1994, terj. Muhammad Baqir, ibid, h. 36).

\section{Hak Perlindungan Terhadap Kehormatan Ahl Dzimmah}

Islam sangat memperhatikan dan banyak memberikan perlindungan terhadap kehormatan dan harga diri seorang dzimmi seperti halnya terhadap kaum Muslimin. Siapa saja tidaklah dibolehkan mencaci seorang dzimmi ataupun menunjukan tuduhan palsu terhadapnya, menjelekkannya dengan suatu ucapan yang tidak disukainya, baik yang bersangkutan dengan dirinya sendiri, nasabnya, perilakunya, bentk tubuhnya atau apa saja selain itu yang berhubungan dengannya.

Dalam pendapat dan pandangan lainya Yusuf Qaradhawi mengutip perkataan Syihabuddin al-Qarafi, "Sesungguhnya akad dzimmah mewajibkan berbagai hak untuk mereka, sebab mereka itu berada dalam lingkungan kita, penjagaan kita, dzimmah kita dzimmah Allah, Rasul-Nya dan agama Islam. maka barang siapa membuat pelanggaran atas mereka 
walaupun dengan satu kata busuk atau gunjingan, ia sudah menyia-nyiakan dzimmah Allah, dzimmah Rasul-Nya serta dzimmah agama Islam" (Yusuf Qardawi, 1994, terj. Muhammad Baqir, ibid, h. 37).

Dapat diambil kesimpulan, bahwa Islam tidak akan membiarkan ada kezaliman, atau nama baik seorang tercoreng meskipun ia beragama selain Islam. Bahkan Nabi Muhammad Saw sendiri mendapat teguran, ketika beliau mengira bahwa yang bersalah adalah orang non-Muslim.

\section{Hak Mendapatkan Jaminan Hari Tua dan Jaminan Kemiskinan}

Islam memberikan jaminan kehidupan yang layak bagi orang-orang non-Muslim yang berdiam di daerah kekuasaan Muslimin serta keluarga yang menjadi tanggungan mereka. Sebab mereka adalah rakyat negeri Islam dan menjadi tanggungannnya dan khususnya hak mendapatkan jaminan hari tua dan jaminan kemiskinan. Qaradhawi menyebutkan, bahwa setiap orang yang berlindung di bawah nauangan pemerintahan Islam, akan mendapatkan jaminan kehidupan yang layak bagi dirinya dan keluarganya. Karena mereka mereka merupakan rai" ah (rakyat) bagi pemerintahan Islam dan menjalankan berbagai partisipasi dalam pemerintahan tersebut dengan mempertanggujawabkan seluruh urusan kepemerintahannya (Yusuf Qardawi, 1994, terj. Muhammad Zaini, Hak dan Kewajiban Ahl Adzhimah menurut Yusuf Qardhawi, ibid, h. 17).

Sabda Nabi Muhammad Saw yang artinya: "Setiap kalian adalah pemimpin, dan setiap kalian akan mempertanggung jawabkan dengan kepemimpinannya" (Imam Muslim, n.d. jilid 3, h. 1459).

Menurut al-Qaradhawi, salah satu yang menjadi sandaran hukum, atas diberlakukannya jaminan hari tua dan jaminan kemiskinan bagi ahl dzimmah adalah surat yang ditulis oleh Khalid Bin Walid atas perintah Abu Bakar kepada penduduk Hirah di Irak, isi surat tersebut "orang tua manapun yang sudah tidak bisa bekerja, atau menderita sebuah penyakit (menyebabkan tidak bisa bekerja), atau orang kaya yang mengalami kemiskinan sehingga menerima sedekah, maka aku akan menghentikan kewajiban jizyah. Dia beserta keluarganya berhak untuk mendapatkan santunan dari baitul mal (Abu Yusuf Ya'qub ibnu Ibrahim, 1979, h. 144). Qaradhawi menambahkan, apa yang ditulis oleh Khalid Bin Walid adalah merupakan ijma" dari para sahabat, ini disebabkan berkumpulnya sebagian besar para Sahabat Nabi saat penulisan (Yusuf Qardawi, 1994, terj. Muhammad Zaini, ibid).

\section{Pemikiran Qardhawi tentang Partisipasi Politik Muslim}

Kesetaraan ketika berbicara tentang sebuah keikutsertaan di dalam menentukan jalannya peta hidup yang harus dijalani dalam sebuah diplomasi politik sebagai salah satu bentuk upaya menciptakan kerukunan dan membangun konsepsi Islam rahmatan lil a'alamin. Bentuk ini menjadi sebuah landasan dasar hidup yang berdampingan satu Muslim dengan nonMuslim lainya.

Terlebih kembali apabila ini terjemahan dalam sebuah nilai syariat ibadah dalam hidup bernegara yang selagi dalam kemaslahatan maka sesungguhnya inilah pola yang harus dijaga. Sebagaimana hal sebelumnya yang dijelaskan oleh Qardhawi ketika berbincang soal ahl adzdzimmah yang sama haknya dan harus dicukupi oleh Negara Muslim, serta imbal baliknya memiliki kewajiban yang harus dipatuhi dan dijalankan. Kewajiban yang mesti dijalankan dan dipatuhi seperti terdiri dalam macam; Pertama, wajib di dalam membayarkan sebagaian harta yang menjadi ketetapan negara tersebut. Dua, 
patuh akan hukum dan regulasi undangundang perdata yang lainya, namun hal ini di luar perkara Keyakinan dan prihal yang bersifat intern individu dan Ketiga, Menghargai juga menghormati syiar Islam dan tempat suci orang Islam.

Maka dari penjabaran fakta-fakta sejarah ini, dapat ditarik benang merahnya, bahwa Islam memberikan dan tidak membebani bagi ajaran, kepercayaan dan agama di luar Islam untuk bebas menjabat dalam sebuah jabatan. Mereka dapat barsaing dengan orang Islam, dan diperbolehkan lebih dalam menjabat. Inilah perkara yang sedemikian adanya pada masa lampau. Namun kini Islam menuntut umatnya untuk bisa bersifat progresif dan komprehensif di dalam menentukan sifat dan persaingan yang baik dan bijak dengan orang non-Muslim.

Kemudian uraian tersebut dapat disimpulkan, tidak menjadi hal dalam bernegara yang kompleksitas sekalanya Muslim dan dipimpin oleh pemimpin seperti kepala daerah non-Muslim. Hal ini selalu diberikan koridor selama pemimpin saat memimpin tidaklah disanatkan memiliki dan menaruh dendam atau kebencian kepada Islam. Dan kapasitas serta amanah di dalam pemimpin menjalankan kepemimpinannya.

Dan situasi ini menjadi sebuah pelajaran yang amat berharga bagi umat Islam dan menjadi keprihatinan akan kemunduran orang Islam terkait kondisi sekarang untuk tidak diabaikan. Dan sangat menjadi miris bila pemimpin yang notabene Muslim, malah melakukan tindakan yang secara syariat Islam melakukan hal tercela.

Adapun fakta yang menjadi pendukung teori paparan ini adalah Desa rama puja jika dilihat dari jumlah penduduk berdasarkan agama, maka agama Islam mendominasi, yaitu 3.941 Muslim, 208 non Muslim dan jumlah penduduk Desa Rama Puja secara keseluruhan berjumlah 4.149 jiwa, seperti yang dijabarkan Mustaqim keterangannya dalam wawancara. Dengan jumlah penduduk tersebut, desa Rama Puja dipimpin oleh seorang kepala desa dari non muslim selama tiga periode berturut-turut yaitu dari tahun 2017-sekarang. Dari data tesebut umat Islam menjadi umat yang mayoritas dibandingkan dengan umat yang lain.

Kondisi desa tersebut sangat berbanding terbalik dengan daerah di provinsi bali, di mana mayoritas penduduk bali beragama hindu dan agama islam menjadi minoritas. Berbeda dengan kondisi kedua daerah tersebut, Jakarta yang notabene mayoritas muslim dipimpin oleh non muslim menimbulkan isu nasional.

Berdasarkan fakta tersebut, Indonesia merupakan tempat paling subur untuk menanamkan berbagai benih pemikiran dan sebagai tempat laboratorium ideology dan pemikiran.

\section{KESIMPULAN}

Pergulatan konsep yang disandarkan dengan berbagai bentuk kenyataan terkadang harus menuai berbagai spekulasi dan membutuhkan perhatian khusus. Hal ini sama kaitannya dengan sebuah pembahasan yang berbicara tentang kehidupan umat manusia dengan kadar variatif dalam berhubungan satu dengan lainya. Kehidupan beragama misalnya, banyak pondasi yang sudah tersurat dan tersirat pada kunci Ilahi.

Dan kehidupan bernegara yang semuanya disandarkan atas sebuah apresiatif menurut Islam ialah konsep rahmatan lil a'lamin. Sehingga dalam hal ini salah satunya seperti hubungan yang terjalin antara umat Muslim dan NonMuslim menjadi sebuah kompleksitas satu unsur kepercayaan dari masing-masing individu. Kemudian kita dapat lihat kehidupan bernegara misalnya, akan sangat relatif menemui titik sensitifitas apabila 
pelbagai unsur dan hal nya ditarik kedalam ranah ke-Tauhidan (Agama). Dalam hal ini Yusuf Qardhaqwi menambatkan konsepnya sebagai bentuk hubungan yang terjalin seperti adanya kadar mayoritas dan minoritas yang ditarik bersamaan dalam kehidupan bernegara (politik). Jauh dalam hal ini Qardhawi mengisyaratkan Ahl Dzimmah menjadi konsep dasar jalan kehidupan masyarakat dalam berpolitik dan bernegara.

Konstruksi ini diungkapkan dengan berbagai pertimbangan yang komprehensif antara satu unsur dengan unsur-unsur lainya. Maka, Qardhawi dalam konsep ini membolehkan kesertaan minoritas Muslim berpartisipasi dan hidup di dalam naungan kepemimpinan Non-Muslim. Dengan berbagai catatan yang secara maqosidus syariah tidak merugikan Muslim yang hidup di tangah kalangan dengan berkependudukan Non-Muslim di dalam berbagai aspek kehidupan, mulai dari ekonomi, politik, sosial dan budaya.

\section{REFRENSI}

Abdul Aziz Dahlan. (2006). Ensklopedia Hukum Islam. PT Ichtiar Baru Van Hoeve.

Abu Yusuf Yaequb ibnu Ibrahim. (1979). Al-kharraj. Darul ma "eifah.

Ahmad A. Sofyan \& M. Raoychan Madjid. (2003). gagasan cak nur tentang negara dan islam. titian press.

Ahmad, I. al-Q. M. I. (2005). al-Jami" li ahkami al-Quran. Maktabah asShafa.

Al-Mughni. (n.d.). al-Badai", Ahkam adz Dzimmiyah wal Mustakmanin.

Departemen Agama RI. (2002). Al Qur'an dan Terjemah. DIPONEGORO.

Diana, R. (2009). Partisipasi Politik Muslimah dalam Pandangan Yusuf
Qardhawi. Tsaqafah, 5(2), 289. https://doi.org/10.21111/tsaqafah.v5 i2.129

Durrah, M. as-S. Y. dan A. (2008). Pustaka Pengetahuan al- Quran. angkasa.

Hafizah, R. (2021). Pemahaman Imam Al-Qurthubi Terhadap Konsep Riddah dalam Al- Qur ' an dan Relevansinya dengan Indonesia oleh Allah SWT, yang membimbing riddah, supaya seseorang tidak mudah Memeluk Islam merupakan fitrah bagi manusia dengan rasa tanggung Islam sangat mem. 3(1).

Hamid, A. (n.d.). Al-Wajis. DKI.

Hidayat, R. (2019). Konsep Pendidikan Karakter Dalam Pengembangan Masyarakat Islam (Studi Pemikiran Burhanuddin Al-Zarnuji). Alfuad: Jurnal Sosial Keagamaan, 3(2), 1. https://doi.org/10.31958/jsk.v3i2.16 92

Ibnu Manzur. (2003). Lisan al-'arab. Dar al hadis.

Imam as-Shayuthi. (1999). al-Jami asshagir.

Imam Baihaki. (1984). Sunan alKubra. Darul mae arif Usmaniyah.

Imam Muslim. (n.d.). Shahih Muslim (Jilid III).

Imam Muslim. (2000). Shahih Muslim. Maktabah Dahlan.

Jarir, I. at-T. M. I. (1995). Tarikh atThabari. darul ma'arif.

kamaruzzaman. (n.d.). relasi islam dan negara: perspektif modernis dan fundamentalis. kamus.

Kartini Kartono. (1980). Pengantar Metodologi Research sosial. Alumni.

Marianne Jorgensen dan Louise Phillips. (2002). Discourse Analysis as Theory and Method. Sage.

Muhammad Ābid al-Jābiri, A.-D. (2003). Mujiburrohman (Terjm). 


\section{LKIS.}

Muhammad al-Ghazali. (1980). Attasamuh baina al-Islam wa alMasihiyah. Nahdatul Misr.

Muhammad as-Sayyid Yusuf dan Ahmad Durrah. (n.d.). PUSTAKA PENGETAHUAN AL QUR'AN.

Muhammad ibn Ahmad ibn al-Juza'i al-Kalabi. (n.d.). Al-Qawanun alFiqhiyyah fi Talkhias al-Mazhab alMalikiyyah. Dar al-Qalam.

Muhammad Murtada al-Husaini alZabidi. (1965). Taj al-Arus Min Jawahir al-Qamus. Hukumah.

Noeng Muhajir. (1996). Metode penelitian Kualitatif. Rake Serasin.

Sayyid Sabiq. (2007). Fiqh al-Sunnah. Pena Pundi Aksara.

Sobry Sutikno. (2014). Pemimpin dan Kepemimpinan. holistica.

Sugianto, S., \& Hidayat, R. (2021). Moderasi Beragama Sebagai Jalan Dakwah Mayoritas Muslim Pada Minoritas Non Muslim. Jurnal Bimbingan Penyuluhan ..., 3(1), 23-41. https://ejournal.metrouniv.ac.id/index.php/J BPI/article/view/3270

Thantawi, M. S. (n.d.). Tafsir alWashit.

Tim Sinar Grafika. (2005). Undangundang Nomor 32 Tahun 2004 tentang Pemerintahan Daerah. Sinar Grafika.

Yusuf Qardawi. (1994). Ghairu al Muslim fii Mujtama' al islami. MIZAN.

Yusuf Qardawi. (1997). al-Halal wa al-Haram fi al-Islam. Maktabah Wahbah.

Zuhraini. (2014). Islam: Negara, Demokrasi, Hukum, dan Politik. Jurnal Studi Keislaman, 14(1), 2958. 